\title{
Detecting the Use of Undisclosed Privileged Information
}

\author{
Elli Kraizberg*
}

Bar Ilan University, School of Business, Ramat Gan 52520, USA,

\begin{abstract}
Enforcing regulators worldwide are mandated to discourage the use of privileged undisclosed information in security trading, as it may distort the true relative prices of securities and may lead to a market failure. This may be an impossible task, given the huge number of indications of such suspicious activity. Deviations of the bid-ask spreads from the optimal spreads provide real-time indications that some market participants may possess undisclosed privileged information. If we relied only on the real-time information that the bid-ask spreads deviate from the theoretical optimal spreads, our 3-years sample would generate over $11 \mathrm{M}$ deviations. This quantity of indications is unmanageable, both for the enforcing regulator, and for the uninformed market participants.

In this study, we construct a mechanism that will enable market participants to significantly reduce the number of suspected cases to a manageable number. We establish an ex-post calibrated likelihood index that estimates the likelihood that profit-oriented traders desire to exploit undisclosed privileged information that they possess. Our mechanism is based on the hypothesis that at any point in time when the likelihood index that predicts how likely traders are to exploit privileged information is positively correlated with an abnormal increase in the bid-ask spreads, then, probabilistically, these transactions should be suspected cases of illegal price-distorting trading.
\end{abstract}

Keywords: Insider trading, Privileged information, Bid-ask spread.

\section{INTRODUCTION}

The legal prohibition on the use of private information is hardly a consistent one when it comes to the definition of illegal use of privileged information. Insiders, who are likely to possess superior privileged information, are allowed to trade provided that they report and disclose their trades, while a trader who is not labeled as an insider is prohibited from trading while utilizing superior private information. The majority of studies that have been done regarding the use of privileged information analyze the impact of reported insider trading. Uninformed traders may not accurately assess the information content of the news regarding insider trading, as the motivation for this trading could be unrelated to whether or not insiders who trade possess privileged undisclosed information. Thus, the market underreact or moderately reacts to publicly released information that an insider has traded, and excess returns subsequent to news of insider trading is not in violation of market efficiency.

On the other hand, it may be "too late" for the uninformed trader who follows reported legal insider trading, as insiders may rationally continue to extract excess returns as long as the market price does not fully reflect the full value of the privileged information that they possess. This may not be the case in the event of illegal undisclosed trading that utilize privileged information, because the well-informed traders try to conceal any indications of their activity. This is also the

*Address correspondence to this author at Bar Ilan University, School of Business, Ramat Gan 52520, USA; Tel: +972586166656;

E-mail: ekraizberg@gmail.com obvious reason why the empirical results for such indications are inconclusive.

Tracing indications of unreported trades, which rely on privileged information, is an important issue for both uninformed traders and the regulators who use, among other techniques, sophisticated electronic surveillance methods. Yet, the role of the regulators is to discourage such trading rather than serving as an informational tool, as the regulators' actions are not known to the public in real time. Thus, the sole remedy available for an uninformed trader is to rely on probabilistic methods, i.e., tracing indications of illegal trading that may increase the probability that they may obtain excess returns.

Our focus in this paper is to assess the existing methods for tracing indications of trades that rely on privileged information and to propose a different approach to this issue. We do not wish to dwell on the following issues, which have attracted the attention of researchers in the past sixty years. First, we do not wish to address the core issue of whether the use of privileged information in security trading should be banned or partially allowed. Grossman (1976), Grossman and Stiglitz (1980), Fishman and Hagerty (1992), Leland (1992), and others, argue that the use of privileged information may deter uninformed traders from participating in the market, thereby leading to a market failure. On the other hand, Mann (1966) Kyle Foster and Viswanathen $(1985,1993)$ and Smith and Watts (1992) argue that allowing the use of privileged information increases market efficiency as new pieces of information arrive to the market sooner rather than later. Thus, the balance of costs and benefits as a result of the use of privileged information may be in favor of 
legitimizing such trading. Kraizberg (2000) argues that the ultimate beneficiary of the use of privileged information may be the firm's shareholders if the benefits of such trading are embedded in an insiders' market-set compensation package. Seyhun (1992) argues that empirical evidence indicates that stronger enforcement measures against the use of privileged information do not deter this illegal activity. Kim and Verrocchio (1997) and Agarwal and Nasser (2012) put forward the interesting thesis that it may be beneficial to those who trade on privileged information to disclose it to the public, obviously after they trade, since prices may increase further after the disclosure.

Second, we do not wish to dwell on the definition of "insiders" who may or may not possess privileged information. Lin and Howe (1990), Iosco (2003) snd Minenna (2003), classify insiders based on the firm's internal hierarchy. Holden and Subrahmanyam (1992) classify insiders by the type of information, i.e., short versus long term information. ${ }^{1}$

Third, we do not wish to analyze the implications of empirical studies that have traced positive excess returns following the announcement of insider trading (Rogof (1964) and Glass (1966) find excess returns of over 9\% in the US, and many subsequent studies demonstrate similar results (Pratt and DeVere 1970; Lorie and Niederhoffer1968; Jaffe 1974; Finnerty 1976; Lin and Howe 1990; Givoly and Palmon 1985; Damodaran and Liu 1993; Kumar and Pupesco 2014). Other studies that were performed outside the US demonstrate similar results (Del Brio et al. 2002 in Spain; Marshall and Hiller 2002 in UK; Hauser and Kraizberg 2003 in Israel; Thalassinos et al.2012 in Greece; Mudalige et al. 2016 in Australia).

We need, first, to define the "event" as a piece of significant news that is released to the public on a certain date, excluding news released after insiders trading data becomes public. The significance of the news is assessed ex-post based on the market reaction after the news is released. The most common events that are studied in the literature are mergers and acquisitions, quarterly reports and dividend changes (Keown and Pinkerton 1981; Meulbroek 1992; Zdanowicz 1992; King 2009; Agrawal and Nasser 2012; Sunderman 2014).

There are three types of methodologies that are used in the literature, either to detect the use of undisclosed privileged information, or to assess the informational content of the disclosure of data regarding insider trading. The first approach utilizes Cumulative Abnormal Returns as a potential indication of the use of privileged information. The CAR is computed using a single market factor or multiple factors (see MacKinlay 1997, for a summary). The CAR is defined as follows:

$|C A R|_{j \tau}=\int_{t}^{\tau} A R_{j t} d t$,

The AR is based on a single-factor model,

$$
A R_{j}=\left(R_{j}-R^{f}\right)-\beta_{j}\left(R_{m}-R^{f}\right)=\widehat{R}_{j}-\beta_{j} \widehat{R}_{m}
$$

\footnotetext{
${ }^{1}$ See also Kyle (1985) ;Glosten and Milgrom (1985) ;Easley and O'Hara (1987) ;Hirshleifer (1971) ;Fama and Laffer (1971) ;Easley, Kiefer and O'Hara (1997)
}

where $R_{j}$ is the actual return of security $\mathrm{j}, R_{m}$ is the market return and $R^{f}$ is the riskfree rate of return for a period of $\tau$-t.

Eq. (2) represents the common way of computing the CAR for traders who follow the news that insiders have just reported their trades.

Jaffe (1974) expresses (2) in terms of the residuals:

$$
\widehat{R}_{j}-\beta_{j} \widehat{R}_{m}=\varepsilon_{j} \text { and thus, }|C A R|_{j \tau}=\int_{t}^{\tau} \varepsilon_{j t} d t
$$

Note, however that the actual CAR for traders who exploit privileged information is significantly higher. For positive news, (2) is an accurate description of the CAR, but for negative news, it is either twice the absolute value of (2) if they can sell short, or the absolute value of (2) if they sell their prior holdings before the news is released. Since we have no way to know the actual CAR of those who exploit privileged information, the simple CAR in (2) is used to detect such activity. For example, Meulbroek (1992) reports the CAR as an indication of trading that utilizes privileged information. Huang and Lin (2007) detect positive excess returns prior to the release of quarterly reports. Chakravarty and McConnell (1999) find that activities of court-confessed users of privileged information prior to the "event" is not statistically significant. Givoly and Palmon (1985) and Morse and Richardson (1984) raise some doubts about the above results by reporting excess returns following insider trading even in the absence of specific "events". Furthermore, Lakonishok and Lee (2001) argue that the main reason for insiders' sale orders is the need for liquidity rather than an attempt to benefit from privileged information.

The use of the simple CAR in (2) as a single indication of the use of privileged information may be problematic for several reasons. The most critical issue is the identification of the factors (single or multiple) that define the so-called normal return. In other words, if the factors are not accurately identified, deviations from zero excess returns may be explained by factors other than the use of privileged information. Furthermore, estimation of the coefficients of the factors would have change, had we known the nature of the new information.

The second common approach to detecting the use of privileged information utilizes technical indicators such as unusual trading volume or unusual changes in volatility. The first such study was conducted by Tinic and West (1972), followed by Morse (1980), Kyle (1985), Admati and Pfleiderer (1988), Cornell and Sirri (1992), Gervais, Kaniel and Mingelgrin (2001), and others. ${ }^{2}$

The third well-established approach utilizes significant changes in the bid-ask spreads as indications of the use of privileged information. Demsetz (1968) and Bagehot (1971) suggest that profit-oriented market makers price the risk of undetected trades that rely on superior privileged information, by setting the bid-ask spreads accordingly. The liter-

\footnotetext{
${ }^{2}$ Kim and Verrecchia (1991);Keown et al. (1992);Bassembinder et al. (1996); Bamber et al. (1999); Easley et al. (2008); Sarkar and Schwartz (2011); Foucault et al. (2011);Chordia et al. (2011);Moshirian et al. (2012); Chae and Yang (2013);Hsieh (2013);Hendershott et al. (2015);Mudalige et al. (2016).
} 
ature on profit-oriented market makers, who set the bid-ask spreads, incorporates both the expected profits that are generated by the market participation of uninformed traders and the expected losses that may be generated by the market participation of traders who possess superior privileged information. A theoretical formulation of the idea is given in Garman (1976), Stoll (1978), Easley and O’Hara (1987), Ho and Stoll (1981), Copeland and Galai (1983) and Glosten and Milgrom (1985).

Empirical evidence that the bid-ask spreads can serve as early warnings of insider trading are not conclusive. The general view is that the conclusion depends on how significant the news is that is about to be released to the public. For example, Conard and Niden (1992) report no significant changes in the bid-ask spreads before quarterly reports are released, and Tripathy and Rao (1992) even report a decline in the spreads before these events. Venkatesh and Chiang (1986) report an increase in the spreads before quarterly reports only when they are accompanied by an unexpected increase in dividends or when firm's announce tender offers to buyback their shares. Barclay and Smith (1988) and Conard et al. (1991) report increases in the spreads when the upcoming news is related to mergers and acquisitions. Foster and Viswanathen (1990, 1993) and Lee et al. (1993) report increases in the spreads only when the news that is yet to be released is significant. Chung and Charoenwong (1998) find that a longer-term policy of the market makers, as opposed to an intra-day policy, in setting the spreads changes over time as a function of the likelihood of participation of traders with privileged information. Bettis, Coles and Lemmon (2000) report an $8.5 \%$ decline in the spread in days in which insider trading was prohibited. Coughenour and Shastri (1999) demonstrate that firm size, trading volume and volatility fully explain the changes in the bid-ask spreads. ${ }^{3}$

This study differs in various ways. First, it establishes a theoretical framework in which the key variable is the bid-ask spread, in the absence of profit-motivated market makers. The changes in the bid-ask spreads are adjusted for changes in the intra-day volatilities of the underlying securities. Then, it establishes an ex-post calibrated likelihood index that includes ex-post observations after the "event", such as, the expost CAR for traders with privileged information, who are assumed to properly predict the market reaction to the disclosed news. The likelihood index is calibrated ex-post for the whole sample of events so that the fixed weights of the components of the index are set. This paper hypothesizes that when the changes in the bid-ask spreads are correlated with the likelihood index, the probability of trades that rely on privileged information increases. In other words, deviations of the bid-ask spreads from the optimal ${ }^{4}$ bid-ask spreads, at any point in time prior to the event, serve as indi-

\footnotetext{
3 See also, Chakravarty, Fishe and McConnell (1997), Garfunkel and Nimalendran (2001), Gleason (2002), who test the spreads following reports of insider trading, Easley, Kiefer, O'Hara and Paperman (1996), Easley, O'Hara and Paperman (1998), Easley, O'Hara and Saar (2001), Easley, Hvidjkaer and O'Hara (2002), Easley and O'Hara (2004), Vega (2006), Odders-White and Ready (2006).

${ }^{4}$ See the framework for establishing optimal bid-ask spreads in the next section. The changes in the optimal spread are adjusted for other parameters such as changes in volatility.
}

cations of suspected trades that rely on private information, if these changes are positively correlated with the likelihood index.

\section{THE MODEL}

\subsection{Market Participants}

We identify three groups of players; uninformed traders (UT) who have long investment horizon and informed traders (IT), who execute short-term trades and have a better knowledge of the true securities prices that are evaluated based on all publicly available information. The latter set the bid-ask spreads, expecting short-term profits when uninformed traders of opportunity come to the market. ${ }^{5}$ The third group of participants, (IN), are profit-seekers who trade when they have privileged information that suggests that the true price is different from the one evaluated based on publicly available information. Some of the IN, who may be labeled as "insiders", report their trades ex-post and some do not. The point of reference or the "event" is the date on which a significant piece of news is disclosed and becomes public knowledge.

\subsection{Contemporaneous Prices}

At any point in time, there are three different prices for the same the security: the bid price, the ask price and the true price that reflects all publicly available information. The homogeneous IT are assumed to have a better knowledge of the true price which, according to their valuation, fluctuates between the bid and ask prices.

Prices fluctuate in a continuous fashion; therefore, we make a fairly strong, yet common assumption that IT can replicate a position at the true price by using substituted securities. This enables IT to extract arbitrage profits when the true price fluctuates between the bid and ask prices. UT, on the other hand, may be aware that the executed transactions at the bid and ask prices command a premium, in relation to the true price, but they are willing to pay this premium in exchange for immediacy (Demsetz 1968). IN are assumed to know the incremental value of the privileged information that they possess.

\subsection{The Setting}

We analyze two scenarios, each with two sub-scenarios: (i) IT refrain from holding any security at any point in time and,

\footnotetext{
${ }^{5}$ The empirical part of this study is done in the Tel Aviv Stock Exchange. Thus, the role of the market makers is omitted because the market makers in the TASE receive indirect benefits for being market makers, and not the traditional direct trading benefits that, for example, market makers in the US may extract. The Israeli SEC enacted the system of market makers in 2003. As of 2017 there were market makers for only 247 securities. Market makers are obliged to provide bid-ask spreads during the entire trading day, except for a 100-minute break. The required minimal amount for each side of a spread is negligible (2000-20000 NIS) and the spread may not exceed $2 \%-8 \%$, depending on the category of securities. In exchange, the market makers receive benefits, which are unrelated to the actual trading of the securities that they provide the bid-ask spreads for. There is an extensive body of literature analyzing the role of market makers in the US, with various assumptions such as risk attitude, horizon, size, etc. See Armstrong (1995) for a good summary.
} 
trading is (a) halted, or (b) not halted, after a release of new information. (ii) IT hold one unit of a security at any point in time, and, trading is halted or not after a release of new information.

\subsubsection{IT Holds no Position}

Hypothetically, assume the absence of IN; i.e., only IT and UT trade in the marketplace. The optimal strategy of IT, who maximizes their expected gains in the event of an order of opportunity on the part of UT, is to insert orders at the bid and ask prices, and to adjust them continuously as the true price changes. In the event of halted trading after any announcement of a new piece of information, which allows IT to adjust their bid-ask spreads, the sole source of uncertainty is the likelihood that UT will place an order. In other words, the expected payoff is always nonnegative, which obviously constitutes an arbitrage opportunity.

If UT executes an order to sell to IT at the bid price, IT will simultaneously buy a replicated position using substituted securities. If, however, UT place an order to buy from IT at the ask price, IT will simultaneously sell short a replicated position using substituted securities. In both cases, the final net holdings of the IT are nil.

Let $f(S)$ be the continuous density function of the true price at any point in time. $\mathrm{S}$ can change in the absence of new idiosyncratic information, for example, due to changes in the market cost of capital, etc. The expected cash flows for IT are:

$p^{+} \int_{0}^{s_{a}}\left(S_{a}-S\right) f(S) \mathrm{d} S+$

$p^{-} \int_{S_{b}}^{\infty}\left(s-S_{\mathrm{b}}\right) f(s) \mathrm{d} S$

Where $P^{+}$is the probability that a buy-order will be placed by UT at the ask price of IT, $S_{a}$, and $P^{-}$is the probability that a sell-order will be placed by UT at the bid price of IT, $S_{b}$. Trivially, if the probabilities are dependent upon the size of the spread, $\left(S_{a}-S_{b}\right)$, i.e., the smaller the spread is, the more likely an order to be placed by UT to enter, then, $S_{a}$ and $S_{b}$ are set such that the elasticity of the probabilities to the size of the spreads equals one (see formulation below).

Initially, we assume that trading is halted upon the release of any type of new information. If IT adjusts the bid and ask prices continuously in the absence of announcements of new information, it is unlikely that $\mathrm{S}$ will diverge from the range of $\left\{S_{a} \ldots S_{b}\right\}$. If, instead, IT are not able to adjust the bid and ask prices continuously, as $\mathrm{S}$ changes, then, excess profits on the bid side, for example, when $\mathrm{S}$ exceeds $S_{a}$ will be fully offset by a potential similar loss on the ask side (assuming that $P^{+}=P^{-}$). Thus, (4) becomes,

$p^{+} \int_{S_{b}}^{S_{a}}\left(S_{a}-S\right) f(S) d S \geq$

0 , and, $p^{-} \int_{S_{b}}^{S_{a}}\left(S-S_{b}\right) f(S) d S \geq 0$

Thus, without loss of generality, we assume that IT change the bid and ask prices continuously.

We now add to our analysis the third group of market participant, IN, who may possess superior privileged information.
IN may know that the true price that reflects their private information, diverges from the current bid-ask spread, and therefore trade with IT at the bid or the ask prices. ${ }^{6}$ IT may not be able to offset the new position (short or long) at a price within the bid-ask spread and thereby may sustain a loss. In other words, IT should consider the risk of a loss if the trade is executed with a market participant who possesses superior information. The risk stems from the fact that IT, may not be able to offset the new position, traded with IN, using substituted securities. IT are the "doorkeepers", who sense that new undisclosed information affects trading. As IT are the first market participants to sense that someone in the market trades based on superior privileged information, they price this risk ex-ante into the optimal bid-ask spreads. This risk premium may vary over time depending on IT's perception of the likelihood that IN are involved.

Formally, let $P^{n}$ be a measure of the likelihood that IN who possess new undisclosed information wish to trade $\left(P^{n+}\right.$ for positive and $P^{n}$ - for negative information).

The expected loss for IT is:

$p^{n+} \int_{S_{a}}^{\infty}\left(S-S_{\mathrm{a}}\right) f(S) d S+$

$p^{n-} \int_{0}^{S_{b}}\left(S_{b}-S\right) f(S) d S \geq 0$

IT faces a similar risk when announcements of new information are not followed by the decision to halt trading for a certain period. There are two differences in the characteristics of the risk associated with IN trading and the risk associated with non-halted trading. By definition, if IN are not involved, then IT has no prior clue of the likelihood of arrival of new information. Thus, the logical remedy is to assume that the density function describes a "jump" process. Yet, if IN are involved, then the two risks, the IN trading risk and the non-halted trading risk are correlated, as involvement of IN serves an indication that a new piece of news is about to be released.

We begin with the simpler case, in which IT maximize net cash flows, $\pi_{I T}$, in the event of definitely positive cash flows as in (5) and expected loss as in (7). However, it must be true that the overall expected cash flows are positive and sufficiently large to compensate IT for the overall risk:

$$
\begin{aligned}
& \operatorname{MAX}_{S_{a}, S_{b}} \pi_{I T}=p^{+} \int_{S_{b}}^{S_{a}}\left(S_{a}-S\right) f(S) d S+ \\
& p^{-} \int_{S_{b}}^{S_{a}}\left(S-S_{b}\right) f(S) d S- \\
& \left(p^{n+} \int_{S_{a}}^{\infty}\left(S-S_{a}\right) f(S) d S+\right. \\
& \left.p^{n-} \int_{0}^{S_{b}}\left(S_{b}-S\right) f(S) d S\right) \geq 0 \\
& \text { s.t. } S_{a} \geq S_{b}>0 \text { and } \pi_{i t} \geq \pi_{i t}>0
\end{aligned}
$$

where $\pi_{i t}$ is the overall risk premium, required by IT.

One trivial solution is that $S_{a}-S_{b}=\infty$, but if $\mathrm{P}^{+}$and $\mathrm{P}^{-}$are dependent on the size of the spread, then, $\mathrm{P}^{+}$and $\mathrm{P}^{-}=0$, i.e., the likelihood that UT will trade with IT is nil and therefore $\pi_{I T}^{*} 0$.

${ }^{6}$ We exclude IN trades within the bid-ask spread. 
We need, therefore, to identify the parameters of the demand function of UT, i.e. the trading likelihood as a function of the size of the bid-ask spread. Formally,

$$
p^{-}=\alpha^{+}+g^{-}\left(S_{a}-S_{b}\right) \text { and } p^{+}=\alpha^{-}+g^{+}\left(S_{a}-S_{b}\right)
$$

subject to boundary conditions, $g(\infty)=0$ and $g(0)=1$

Since $\mathrm{a}^{+}$and $\mathrm{a}^{-}$capture other factors that explain the arrival of UT to the market, it is reasonable to assume that the elasticity of demand in (10) is between zero and -1 . In other words, the percentage change in the probability that UT will be willing to trade with IT is smaller than the percentage change in the spread, due to other factors that drive UT to trade (this assumption is validated empirically). Thus, it must be true that,

and,

$$
\frac{\partial p^{+}}{\partial \int_{S_{b}}^{S_{a}}\left(S_{a}-S\right) f(S) d S} \frac{\int_{S_{b}}^{S_{a}}\left(S_{a}-S\right) f(S) d S}{p^{+}}<1
$$

$\frac{\partial p^{-}}{\partial \int_{S_{b}}^{S_{a}}\left(S-S_{\mathrm{b}}\right) f(S) d S} \frac{\int_{S_{b}}^{s_{a}\left(S-S_{\mathrm{b}}\right) f(S) d S}}{p^{-}}$

The trivial proof follows directly from the assumption about the elasticity of demand.

\subsubsection{IT holds one Unit at any Point in Time}

This scenario is a bit more realistic and it differs from the previous scenario. IT, instead of requiring positive expected cash flow that exceeds the risk premium, will not require excess return above the normal expected return of the security that they hold and keep at any point in time.

The expected excess rate of return of IT is,

$\left\{\left[p^{+} \int_{S_{b}}^{s_{a}}\left(S_{a}-S\right) f(S) d S+\right.\right.$

$\left.p^{-} \int_{S_{b}}^{S_{a}}\left(S-S_{\mathrm{b}}\right) f(S) d S\right]+[(1-$

$\left.P^{n+}\right) \int_{S_{a}}^{\infty}\left(S-\mathrm{S}_{\mathrm{a}}\right) f(S) d S+(1-$

$\left.\left.\left.p^{n-}\right) \int_{0}^{s_{b}}\left(S_{b}-S\right) f(S) d S+\int_{S_{b}}^{S_{a}} S f(S) d S\right]\right\} / S-$

$\left.\int_{0}^{\infty} s f(s) d S\right) / S \geq 0$

The first [.] represents UT participation, the second [.] represents the behavior of IT holdings, net of potential IN activity, and the last term represents normal returns had they been held continuously.

Rearranging (11) yields the exact payoff as in (8) but in terms of expected rate of return:

$$
\begin{aligned}
& \left\{P^{+} \int_{S_{b}}^{S_{a}}\left(S_{a}-S\right) f(S) d S+\right. \\
& p^{-} \int_{S_{b}}^{S_{a}}\left(S-S_{\mathrm{b}}\right) f(S) d S- \\
& p^{n+} \int_{S_{a}}^{\infty}\left(S-S_{\mathrm{a}}\right) f(S) d S+ \\
& \left.p^{n-} \int_{0}^{S_{b}}\left(S_{b}-S\right) f(S) d S\right\} / S \geq 0
\end{aligned}
$$

\section{ESTABLISHING TESTABLE ALGORITHMS}

We laid down the theoretical framework in Section II. In order to establish testable algorithms, we need to identify a more restrictive structure. The structure is dependent on: (i) whether there is or there is no halted trading after an an- nouncement of new information, (ii) whether IT is able or unable to adjust the bid-ask spread continuously, and (iii) the assumptions on the various probabilities.

Denote the decision variable on the part of IT by $S^{+}$, i.e.,

$S^{*}=\frac{S_{a}-S_{b}}{S}$

\subsection{Trading is Halted Upon Announcements}

Consider first the simplified case, where IT are assumed to be risk-neutral, and all probabilities are equal (i.e. $\mathrm{P}^{n+}=\mathrm{P}^{n-}=$ $\mathrm{P}^{n^{*}}=\mathrm{P}^{n-}$ ), then we do not need to know the size of the probabilities since (12) becomes an equality.

In this case, expressing $=S^{+}$from (12) yields,

$$
\begin{aligned}
& S^{*}=\frac{\int_{S a}^{\infty}\left(S_{a}-S\right) f(S) d S+\int_{0}^{S_{b}}\left(S-S_{b}\right) f(S) d S}{S \int_{S_{b}}^{S_{a}} f(S) d S}= \\
& \frac{\left(C L\left(S, S_{a}\right)+P T\left(S, S_{b}\right)\right)}{S \int_{S_{b}}^{S_{a}} f(S) d S}
\end{aligned}
$$

where CL is a call option with a very short duration, and PT is the corresponding put option, priced based on fundamental option theory. Since it is of a very short duration, $\int_{S b}^{S a} f(S) d S$ can be viewed as a simple density function between two values. $\mathrm{S}$ is the current true price that is perceived by IT.

If, however, IT are not risk neutral and they demand a risk premium of $\overline{\pi_{i t}}$ that is constant for our purposes, but we still maintain fixed $P^{n+}=P^{n-}=P^{n^{*}}=P^{n-}$, then (12) is equal to $\overline{\pi_{i t}} / \dddot{p}$ and (14) is trivially adjusted.

If, however, $P^{+}, P^{-}$are a function of the bid-ask spread as described in (10b), (and $P^{n^{*}}=P^{n-}=P^{n+}$ then (14) becomes an iterative function,

$$
S^{*}=\frac{\left(C L\left(S, S_{a}\right)+P T\left(S, S_{b}\right)\right)+\overline{\pi_{i t}} / p^{+}\left(s^{*}\right)}{S \int_{S_{b}}^{S_{a}} f(S) d S}
$$

The purpose of this study is to track the changes in $S^{*}$. Assuming that the elasticity of demand is constant in the short run, we do not need to model $\overline{\pi_{i t}} / p^{\overline{+}}\left(s^{*}\right)$. Rather we will imply $\overline{\pi_{i t}} / p^{+}\left(s^{*}\right)$ empirically from the initial bid-ask spreads, a day before the test sample begins, and use it as the benchmark spread for subsequent days.

Lastly, we relax the assumption on the probabilities and assume that $P^{n^{*}}=P^{n-}$ and $P^{*}=P^{-}$but $P^{n}$ and $\mathrm{p}$ are not equal to each other. We assume that the a-priori expected change in $P^{*}, P^{-}$is zero (i.e., absent any information that indicates otherwise), and therefore we may empirically imply the initial constant ratio, $P^{\mathrm{n}+} / P^{*}=P^{+}=P$ from the initial bid-ask spreads. While the initial $P^{*}, P^{-}$remains constant, $P^{n+}$ is 
hereafter implied from the likelihood ratio that will be discussed in the next section. Given the above, (15) becomes,

$$
s^{*}=\frac{\frac{\left(c L\left(s s_{a}\right)+P T\left(s s_{b}\right)\right)}{\hat{p}}+\overline{\pi_{i t}} / p}{} \bar{F}_{\left(s^{*}\right)}
$$

\subsection{Trading is not Halted Upon Announcements}

We consider here a case where trading is not halted upon an announcement of new information, and IT may not be able to adjust the bid-ask spread after the news becomes public. Had we assumed that IT is capable of being the first to react to the news, then it would boil down to the previous case; however, we will assume that IT have no such advantage in the event that news is disclosed and trading is not halted.

In this case, the expected cash flows of IT might sustain an additional loss, i.e.,

$$
\begin{gathered}
\pi_{I T}=p^{+}\left\{\int_{s_{b}}^{s_{a}}\left(S_{a}-S\right) f(S) d S+\int_{s_{a}}^{\infty}\left(S_{a}-S\right) f(S) d S\right\} \\
+p^{-}\left\{\int_{S_{b}}^{S_{a}}\left(S-S_{\mathrm{b}}\right) f(S) d S+\int_{0}^{s_{b}}\left(S-\mathrm{S}_{\mathrm{b}}\right) f(S) d S\right\} \\
-\left(p^{n+} \int_{S_{a_{a}}}^{\infty}\left(S-\mathrm{S}_{\mathrm{a}}\right) f(S) d S+\right. \\
\left.p^{n-} \int_{0}^{S_{b^{b}}}\left(S_{b}-\mathrm{S}\right) f(S) d S\right) \geq 0
\end{gathered}
$$

Under our assumptions in the previous case, the bid-ask spread will be set ex-ante as follows:

$$
s^{*}=\frac{2 \frac{\left(c L\left(s s_{a}\right)+P T\left(s s_{b}\right)\right)}{\hat{p}}+\overline{\pi_{i t}} / p^{\mp}\left(s^{*}\right)}{s \int_{s_{b}}^{s_{a}} f(s) d S}
$$

Note that (16) or (18) represent the optimal spread ex-ante, i.e. in the absence of clear indications that IN are active, and the spread merely accounts for the risk that may be active in the future. Our hypothesis is that IT, being the "doorkeepers" will be the first market participants to sense that IN enter the market, possibly with superior privileged information, and therefore, will adjust the bid-ask spread, above to be (16) or (18).

\subsection{The Likelihood Index}

We form an ex-post-calibrated index of the likelihood that IN who possess superior privileged information desire to trade. The calibration will be done ex-post for the entire sample, so that the same coefficients of the index will be used, ex-ante, for each single event. In other words, IT, based on a past learning process have a full knowledge of the coefficients of the index and only a probabilistic knowledge of the values of the parameters, which they use when they sense a suspicious activity by IN. However, even when the "event", i.e., the actual release of new information to the public occurs, the likelihood index remains a probabilistic assessment. The role of the index, therefore, is to reduce the number of suspicious trades in comparison to all trades that deviated from the optimal bid-ask spreads (see Section IV).

The index is linear and includes the following variables:
CL - Type of news. We hypothesize, (following the findings in the literature; see Venkatesh and Chiang 1986, Barclay and Smith 1988, Conard et al. 1991, Foster and Viswanathen 1990, 1993, Lee et al. 1993), that IN are more likely to exploit their privileged information in events such as mergers and acquisitions, tender offers, resignations and appointments, and less in events such as quarterly reports and changes in dividend distributions. We divide the events into six categories; each receives a value from one to six. The nature of the event, known only ex-post, receives a constant value during the entire sample period.

$\mathrm{CR}$ - Exposure to privileged information. The larger the number of individuals who may be exposed to undisclosed information, the more likely someone is to exploit this information. We divide the cases into three categories: only the firm's board of directors has prior knowledge, or the board and the senior management does, or the entire staff of the firm does. Furthermore, news that involves external entities or that involves longer preparation periods receives a higher likelihood value. The value, an integer from one to three, given to this variable may change as we approach the date of the event, if we have reason to believe that a piece of news that originated in the board has been disseminated to the entire firm.

$\mathrm{PN}$ - Positive or negative news. PN+ and PN-, denote whether the news is positive or negative, respectively. Market reaction after the news is announced will determine whether the news is positive or negative. We hypothesize that positive news will have higher coefficients due to shortsale limitations and behavioral bias in favor of positive news.

INF - The level of significance of the news. The more significant the information is, the more likely IN are to trade. This is a continuous variable equal to the ex-post one-day CAR following the announcement of the news. We assume that IN are capable of properly evaluating the immediate market reaction to the news once it is disclosed.

MM - Market makers. This is a dummy variable that receives a value of one if the security has an official market maker, and zero otherwise. We suspect (as described in footnote 5) that due to the fact that market makers in Israel are not motivated by trading profits, this variable will have insignificant coefficients. This will also enable us to validate our hypothesis that the effective bid-ask spreads are set by IT and not by the market makers.

$\mathrm{PF}$ - Time frame of the news. IN are more likely to trade if the new information they possess is relevant to future rather than past performance. It is reasonable to assume that quarterly reports and corrections of previously disclosed reports are less likely to encourage IN to trade. Thus, we divide the sample into three categories, each with an integer value from one to three, representing future relevancy, past relevancy, and undetermined time relevancy.

TIN - The date of the event. This is a continuous variable indicating the number of days left until the news will be announced. It is reasonable to assume that, as we get closer to the date of the "event", IN are more motivated to trade. It is possible that this variable captures some of the effect of CR and other variables. 
PIN - Previous indications. This is a dummy variable representing prior indications, known to the public, of new information, such as previous similar events, unverified rumors, information leakage etc. We omitted observations with prior definite indications that were disclosed to the public and we did not include them in the index.

MC - Market cap. The larger a firm is, the more likely analysts are to watch and evaluate the firm and devote more attention to any prior indications of new information. On the other hand, the larger the firm, the larger the number of people that may be exposed to undisclosed information (CR). We cannot assess a-priori the type of effect that this variable may have, if any.

$\mathrm{RL}$ - Reliability of the information. When a firm makes an announcement of new information, the market does not necessarily evaluate the news at face value. Majluf and Myers (1984), for example, assume an absolute lack of confidence in the firm's announcements, other than the type of financing sought by the firm. This is particularly important when the news is accompanied by the firm's overoptimistic future forecast. The weakness of this factor is the question of whether or not IN can predict the level of market trust in the firm's announcements. If IN believe that the market will not trust the news, they will refrain from trading. One potential indication of the reliability of the information is the ex-post 60-day CAR (as opposed to the ex-post one-day CAR in INF), but we could not include it as an explanatory variable because it is highly correlated with other variables in the index.

In summary, we hypothesize that IN are more likely to exploit privileged information, the higher the expected profits (or loss avoidance) that they can generate. We also believe that since IN can evaluate accurately the final effect of the news, they will realize the gains a significant time after the event (that is, after they sell whatever they purchased, or repurchase whatever they sold, prior to the event; see Hauser and Kraizberg, 2003). Thus, the ex-post 30-days CAR is used as the LHS variable of the following likelihood index:

$$
\mid \text { ExpostCAR }_{30 \text { days }} \mid=f(\mathrm{CL}, \mathrm{CR}, \mathrm{PN}, \mathrm{INF}, \mathrm{PF}, \mathrm{TIN}, \mathrm{MM})
$$

(19) does not represent a cause-and-effect relationship. Rather, it is an outcome of possibly exogenous factors beyond the scope of this paper. We might as well write (19) as an implicit function equal to a constant. ExpostCAR 30 days , as discussed above, may be different for IN than the CAR defined in (2), since IN can extract an even higher CAR by selling short (or liquidating holdings) when the nature of the news is negative.

In order to determine the weights of each variable, we will calibrate the index using the entire sample, computing the likelihood ratio that is asymptotically chi-squared distributed (Wilks's theorem, 1938). This procedure involves a tremendous number of iterations to obtain a statistically significant, set of coefficients (an optimal set, but not necessarily the most optimal).

Finally, we hypothesize that at a point in time when the likelihood index was positively correlated with an abnormal in- crease in the adjusted bid-ask spread, then probabilistically, IN were participating in the market in an attempt to exploit their privileged information.

\section{THE DATA}

The data includes several sets as follows:

Set A - Announcements made by Israeli TASE-listed firms during 2015-2017, if the underlying securities had an officially designated market maker. ${ }^{7}$

Set B - Announcements made by Israeli TSAE-listed firms during 2015-2017 if the underlying securities did not have a market maker.

Set C - Daily trading data from 30 to 24 days prior to the announcements and 1 to 30 days after the announcements. The data includes closing prices, max-min bid-ask spreads, volume, average volatility, and forward 5-day beta. ${ }^{8}$

Set D - Intraday data 5 days prior to the announcements. The data includes every single transaction, the book of orders, and 3 ask and bid prices on each side.

\subsection{Definition of the Variables}

Bid-ask spreads. We use two measures of the spreads: the lowest ask price less the highest bid price and the volumeweighted average bid-ask spread of the three lowest ask prices and the three highest bid prices. The first measure fits the arguments of this paper, but the second measure may contain some information as well.

Standard deviation. For set D, the annualized intraday standard deviation $\sigma_{a}=\sigma_{d} \sqrt{365}$ is used and for set $\mathrm{C}$, the annualized forward 5-days standard deviation is used. We use a slack variable to assure continuity in the measure of the standard deviation from day 6 to day 5 , prior to the announcements.

Positive, negative, and significant news. We believe that it is inappropriate to model the valuation of the news based on ex-ante expectations, as some of the news is unexpected. Instead, we assess the new information based on the ex-post market reaction, i.e. the one-day CAR and the 30-day CAR.

Probability of arrival of UT to the market. We use two methods for calculating the probabilities that are embedded by IT in setting the bid and ask prices. First, assuming that 30 days prior to the announcement the likelihood of any related activity on the part of IN is very small, we can imply the probabilities from the actual bid-ask spread on the 30th day prior to the announcement. The second method is the actual frequency of arrival of UT to the market. Let $n_{t-i}, i=1 . . m$ be the number of days (out of $\mathrm{m}$ days) prior to date $\mathrm{t}$, in which the security was traded $\mathrm{n}$ or more times. We arbitrarily set the probability to be $p^{+}=p^{-}=n_{\tau-i}, i=1 . .5 / m$. Using the first method we calibrated $\mathrm{n}$ and $\mathrm{m}(\mathrm{n}=3, \mathrm{~m}=5)$.

\footnotetext{
${ }^{7}$ Source: MAYA, the official Israel SEC cite.

${ }^{8}$ Source: Data supplied by the TASE
} 


\subsection{Descriptive Statistics of the Data}

Table 1 presents a summary of the data:

Table 1. Description of the data.

\begin{tabular}{|c|c|}
\hline Number of events (announcements) & 600 \\
\hline $\begin{array}{c}\text { Number of observations days } 6 \text { to day } 30 \text { prior to an- } \\
\text { nouncements (daily) }\end{array}$ & 15,000 \\
\hline $\begin{array}{c}\text { Number of observations days 5 to day 1 prior to announce- } \\
\text { ments (intraday) }\end{array}$ & $10,889,845$ \\
\hline $\begin{array}{c}\text { Number of observations with no halted trading after an- } \\
\text { nouncements }\end{array}$ & $9,725,040$ \\
\hline $\begin{array}{c}\text { Number of observations with halted trading after an- } \\
\text { nouncements }\end{array}$ & $1,182,305$ \\
\hline Number of observations with designated market makers & $9,935,034$ \\
\hline $\begin{array}{c}\text { Number of observations without any designated market } \\
\text { makers }\end{array}$ & 972,311 \\
\hline $\begin{array}{c}\text { Number of observations at the end of the day of announce- } \\
\text { ments, }\end{array}$ & 600 \\
and 60 days CAR after announcements & 600 \\
\hline
\end{tabular}

The number of observations represents the actual number of transactions and the bid-ask spread at the same time, or, alternatively, a significant change, as defined in Table $\mathbf{4}$, in the bid-ask spreads with no transactions at the same time.

The components of the likelihood index are described in Table $\mathbf{2}$ and Table 3, which analyze the types of events as well:

Table 2. Range of values for the likelihood index.

\begin{tabular}{|c|c|c|c|c|}
\hline Variable & values & $\begin{array}{l}\text { Average } \\
\text { score }\end{array}$ & $\begin{array}{l}\text { Standard } \\
\text { Deviation }\end{array}$ & Type \\
\hline$C L$ & $\begin{array}{l}\text { Financing, rating } \\
\text { Legal actions, State } \\
\text { intervention } \\
\text { Quarterly reports, } \\
\text { dividends } \\
\text { Resignation, ap- } \\
\text { pointment, board } \\
\text { New purchase, new } \\
\text { line, cooperation } \\
\text { Tenders, M\&A } \\
\text { transactions with } \\
\text { control owner }\end{array}$ & 3.5668 & 1.6887 & Constant \\
\hline$C R$ & $\begin{array}{c}\text { Board exposure } \\
\text { Senior management } \\
\text { exposure } \\
\text { Entire firm and } \\
\text { outsiders }\end{array}$ & 2.6 & 0.74 & $\begin{array}{l}\text { May vary } \\
\text { over time }\end{array}$ \\
\hline
\end{tabular}

\begin{tabular}{|c|c|c|c|c|}
\hline$P N$ & $\begin{array}{l}\text { 1-Positive one-day } \\
\text { market reaction } \\
\text { 0-Negative one-day } \\
\text { market reaction }\end{array}$ & 0.472 & 0.4992 & Constant \\
\hline$I N F$ & $\begin{array}{c}\text { Level of significance } \\
\text { - one-day market } \\
\text { reaction }\end{array}$ & $\begin{array}{l}0.0446 \\
-0.0275\end{array}$ & $\begin{array}{l}0.1281 \\
0.1664\end{array}$ & $\begin{array}{l}\text { Continu- } \\
\text { ous }\end{array}$ \\
\hline$M M$ & $\begin{array}{c}\text { Set A - fraction of } \\
\text { announcements / } \\
\text { MM } \\
\text { Set B - fraction of } \\
\text { announcements / no } \\
\text { MM }\end{array}$ & & $\begin{array}{l}0.204 \\
0.796\end{array}$ & Constant \\
\hline$P F$ & $\begin{array}{l}\text { 1- Past relevancy } \\
\text { 2-Past and future or } \\
\text { undeterminable } \\
\text { 3-Future relevancy }\end{array}$ & 2.2301 & 0.6532 & Constant \\
\hline$T I N$ & $\begin{array}{l}\text { Number of days } \\
\text { before the an- } \\
\text { nouncements }\end{array}$ & & & $\begin{array}{l}\text { Vary over } \\
\text { time }\end{array}$ \\
\hline$M C$ & $\begin{array}{l}\text { The NIS value of all } \\
\text { outstanding shares } \\
\text { (in Billions of NIS) }\end{array}$ & 6.3628 & 25.5207 & $\begin{array}{l}\text { Continu- } \\
\text { ous }\end{array}$ \\
\hline
\end{tabular}

Table 3. One-way ANOVA for the types of events.

\begin{tabular}{|c|c|c|c|c|}
\hline & $\mathrm{N}$ & M & SD & \multirow{7}{*}{$\begin{array}{c}F= \\
1.22, \\
p=0.30\end{array}$} \\
\hline 1-Financing, rating & 141 & $-0.24 \%$ & $13.51 \%$ & \\
\hline $\begin{array}{l}\text { 2-Legal actions, State } \\
\text { intervention }\end{array}$ & 89 & $0.38 \%$ & $4.25 \%$ & \\
\hline $\begin{array}{c}\text { 3-Quarterly reports, divi- } \\
\text { dends }\end{array}$ & 106 & $2.38 \%$ & $3.92 \%$ & \\
\hline $\begin{array}{l}\text { 4-Resignation, appoint- } \\
\text { ment, board }\end{array}$ & 62 & $0.11 \%$ & $7.27 \%$ & \\
\hline $\begin{array}{l}\text { 5-New purchase, new } \\
\text { line, cooperation }\end{array}$ & 36 & $-0.02 \%$ & $6.27 \%$ & \\
\hline $\begin{array}{l}\text { 6-Tenders, M\&A transac- } \\
\text { tions with control owner }\end{array}$ & 166 & $2.52 \%$ & $14.07 \%$ & \\
\hline
\end{tabular}

\section{FINDING}

We chose the most significant likelihood index using a very large number of iterations. The selected model has a chisquare of 334.294 , and $\mathrm{p}<.001$. Nagelkerke $R^{2}$ explains $12.1 \%$ of the variance. Table 4 summarizes the significant components of the likelihood index that was selected. 
Table 4. The likelihood index.

\begin{tabular}{|c|c|c|c|}
\hline Variable & Coefficient & Wald test & P-value \\
\hline CL & -0.891 & 22.254 & $<.001$ \\
Sub-groups of CL: & & & \\
CL(1) & -1.222 & 10.064 & .002 \\
CL(3) & -0.490 & 4.493 & 0.034 \\
\hline CR & -1.213 & 20.111 & $<.001$ \\
Sub-groups of CR: & & & \\
CR(2) & -.619 & 6.175 & .013 \\
CR(3) & -1.551 & 17.549 & $<.001$ \\
\hline MC & -.148 & 14.422 & $<.001$ \\
\hline TIN & .029 & 18.218 & $<.001$ \\
\hline Constant & -3.428 & 262.102 & $<.001$ \\
\hline
\end{tabular}

An increase in the bid-ask spreads ${ }^{9}$ is defined as a deviation, if the spread is one standard deviation above the optimal bidask spread as established in Section II. The constant standard deviation was calculated ex-post for the five days prior to the announcements (using intraday observations).

In order to understand our finding, we reiterate our hypothesis: the likelihood index represents the probability that there are profit-maximizing IN with privileged information who have knowledge of the parameters of the index, and therefore desire to trade and exploit the privileged information that they possess. In real time, even if non-IN traders know the coefficients of the index, they are unable to assess the values of the parameters in the index, which can be assessed only by IN. In other words, IN who know the nature of the information form expectations with respect to the parameters in the index, such as the ex-post CAR. In addition, we assume that in real time IT may suspect that there is some activity of IN in the market, and therefore may increase the bid-ask spreads. Ex post, we can measure the correlation between the likelihood index and the deviations of the bid-ask spreads. All the deviations of the bid-ask spreads that are correlated with the likelihood index are considered to be "suspicious" trades by IN. By setting a cutoff value of the correlation, we can significantly reduce the number of suspected trades by IN. This information is very useful for all market participants and for the enforcing regulators, as will be discussed in the conclusion.

Thus, our goal is to identify a manageable subset of the deviations, which will be labeled as "suspicious" IN trading, by setting a cutoff rate. We could interchangeably use the cutoff rate as the size of the deviations of the bid-ask spreads (in terms of $s^{*}$ ), or as the level of correlation of the likelihood index. Interestingly, our finding indicates that two cutoff criteria do not coincide around deviations above $6 \%$, and the highest correlation between the likelihood index and the de-

\footnotetext{
${ }^{9}$ Measured as the difference between the lowest ask price less the highest bid price at any point in time, or, alternatively, the volume-weighted average of the three lowest ask prices and the three highest bid prices.
}

viations of the bid-ask spreads occurs at about $9 \%$ deviation. Thus, in Table $\mathbf{5}$ we report the number of suspicious observations (out of a total of $11 \mathrm{M}$ observations) as a function of the cutoff rate for the smaller deviations, and in Graph 1 we analyze the relationship between the size of the deviations and the level of the correlations for deviations greater than $6 \%$.

Table 5. Number of suspicious observations as a function of the cutoff rate (for the smaller deviations).

\begin{tabular}{|c|c|c|c|}
\hline Critical cutoff $R^{2}$ & $\begin{array}{c}\text { Average Excess devia- } \\
\text { tion (in terms of s*) }\end{array}$ & $F$ & $N$ \\
\hline 0.001 & $0.031 \%$ & $2423.518^{* *}$ & 246,404 \\
\hline 0.01 & $0.078 \%$ & $7783.730^{* *}$ & 184,460 \\
\hline 0.015 & $0.085 \%$ & $462.644^{* *}$ & 180,205 \\
\hline 0.02 & $0.106 \%$ & $292.884^{* *}$ & 179,363 \\
\hline 0.0215 & $0.132 \%$ & $4065.582^{* *}$ & 174,792 \\
\hline 0.023 & $0.135 \%$ & $2197.637^{* *}$ & 171,189 \\
\hline 0.046 & $0.237 \%$ & $8304.839^{* *}$ & 170,711 \\
\hline 0.18 & $5.12 \%$ & $5.383^{* *}$ & 118 \\
\hline
\end{tabular}

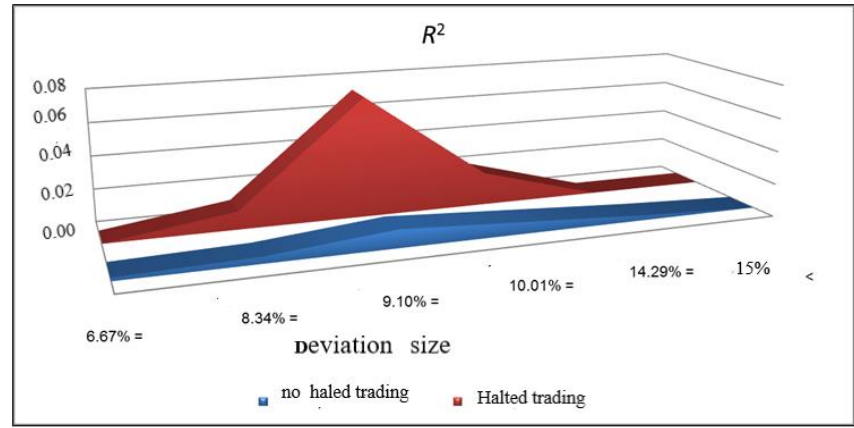

Graph 1. The relationship between the correlation and the size of deviation for large deviations.

We analyzed one further case of a cutoff correlation of 0.1 . The total number of "suspicious" deviations in the bid-ask spreads, as defined above, was reduced to only 18,600 . The various cases for this cutoff rate are given in Table 6 .

Table 6. Correlations of the likelihood index upon deviations of the bid-ask spreads.

\begin{tabular}{|c|c|c|c|}
\hline & $\mathrm{N}$ & Correlation & $\begin{array}{c}\text { Significance } \\
\text { Level } \\
* 0.05, * * 0.01\end{array}$ \\
\hline Total number of deviations & 18600 & 0.0317 & $4.32^{* *}$ \\
\hline Deviations with market makers & 12038 & 0.029 & $3.171^{* *}$ \\
\hline $\begin{array}{c}\text { Deviations without market } \\
\text { makers }\end{array}$ & 6562 & 0.013 & 1.072 \\
\hline Deviations with halted trading & 2108 & 0.047 & $2.146^{*}$ \\
\hline $\begin{array}{c}\text { Deviations without halted } \\
\text { trading }\end{array}$ & 16492 & 0.052 & $6.687^{* *}$ \\
\hline
\end{tabular}




\section{CONCLUSION}

Trading that is aided by new information, possessed by a small group of market participants is illegal if the information is not disclosed to the public. This type of trading may distort the true relative prices of securities and may lead to a market failure. The enforcing regulator is mandated to prevent this type of distortion. This is an impossible task, given the huge number of transactions executed every second. Obviously, uninformed traders are also eager to know if the market security prices represent the true relative values.

Deviations of the bid-ask spreads from the optimal spreads may provide real-time indications that some market participants possess privileged information. If we rely only on the real-time information that the bid-ask spreads deviate from the theoretical optimal spread, we would generate millions of suspected observations. In this study, we construct a mechanism that enables market participants to significantly reduce the number of suspected cases to a manageable number. This is crucial for the enforcing regulator who needs to investigate, ex post, only a manageable number of potentially illegal trades.

Our mechanism is based on the hypothesis that at any point in time when the likelihood index that predicts how likely IN are to exploit privileged information is positively correlated with an abnormal increase in the bid-ask spreads, then, probabilistically, these transactions should be suspected cases of illegal, price-distorting trading. Further research may validate or invalidate our hypothesis by comparing our finding with trading data of IN who have been convicted in court.

\section{CONFLICT OF INTEREST STATEMENT}

The authors declare that they have no conflict of interest.

\section{REFERENCES}

Admati, A.R. and Pfleiderer, P. (1988), "A theory of intraday patterns: volume and price variability", The Review of Financial Studies, Vol. 1 No. 1, pp. 3-40.

Agrawal, A. and Nasser, T. (2012), "Insider trading in takeover targets", Journal of Corporate Finance, Vol. 18 No. 3, pp. 598-625.

Armstrong, V.S., "A Theoretical and Empirical Analysis of Insider Trading Sanctions", PH.D. Dissertation, (1995), Arizona State University.

Bagehot, W., (1971), "The Only Game in Town", Financial Analysts Journal 27, 12-14, 22.

Bamber, L.S., Barron, O.E. and Stober, T.L. (1999), "Differential interpretations and trading volume", Journal of Financial and Quantitative Analysis, Vol. 34 No. 3, pp. 369-386. Barclay, M. and C. Smith, (1988), "Corporate payout policy: Cash dividends versus openmarket re-purchase", Journal of Financial Economics 22 pp. 61-82.

Beny, L. N.. (2007), "Insider Trading Laws and Stock Markets Around the World: An empirical Contribution to the Theoretical Law and Economics Debate", The Journal of Corporation Law pp 237-300.

Bessembinder, H., Chan, K. and P.J. Seguin, P.J. (1996), “An empirical examination of information, differences of opinion, and trading activity", Journal of Financial Economics, Vol. 40 No. 1, pp. 105134.

Bettis, Coles, and Lemmon, (2000), "Corporate policies restricting trading by insiders", Journal of Financial Economics 57,191-220.

Chee, J. and C.W. Yang, (2013), "Commonality in individuals' trading: a systematic path between behavioral bias and expected returns", $P a$ cific-Basin Finance Journal, Vol. 21 No. 1, pp. 1008-1023.

Chakravarty, S. and J.J. McConnell, (1999), "Does insider trading really move stock prices?", Journal of Financial Quantitative Analysis, Vol. 34 No. 2, pp. 191-209.
Chakravarty S., and J. J. McConnell, (1997), "An Analysis of Prices, Bid/Ask Spreads, and Bid and Ask Depths Surrounding Ivan Boesky's Illegal Trading in Carnation's Stock", Financial Management 26, 18-34.

Chordia, T. and A. Subrahmanyam, (2004), "Order imbalance and individual stock returns: theory and evidence", Journal of Financial Economics, Vol. 72 No. 3, pp. 485-518.

Chordia, T., Roll, R. and A. Subrahmanyam, (2011), "Recent trends in trading activity and market quality", Journal of Financial Economics, Vol. 101 No. 2, pp. 243-263.

Chung, K. H. and C. Charoenwong, (1998), "Insider Trading and the BidAsk Spread", The Financial Review 33, 1-20.

Conrad, J. and C. M. Niden, (1992), "Order flows, trading costs and corporate acquisition announcements", Financial Management 21, 2231 .

Copeland TE, and D. Galai, (1983), "Information effects on the bid-ask spread". Journal of Finance 38(5):1457-1469

Cornell, B. and E, R. Sirri, (1992), "The Reaction of Investors and Stock Prices to Insider Trading", Journal of Finance 47, 1031-1059.

Coughenour, J. and K. Shastri, (1999), "Symposium on Market Microstructure: A Review of the Empirical Evidence", The Financial Review 34, $1-28$.

Damodaran, A. and C. H. Liu, (1993), "Insider Trading as a Signal of Private Information", Review of Financial Studies 6, 79-119.

Del Brio E.B., Miguel A., and J. Perote, (2002), "An investigation of insider trading profits in the Spanish stock market". Quarterly Review of Econ Finance 42:73-94

Demsetz, H., (1968), "The Cost of Transacting", Quarterly Journal of Economics 82, 33-53.

Duarte J, and L. Young, (2009), "Why is PIN priced?" Journal of Financial Economics 91(2):119-138

Duong, H.N., Kalev, P.S. and Krishnamurti, C. (2009), "Order aggressiveness of institutional and individual investors", Pacific-Basin Finance Journal, Vol. 17 No. 5, pp. 533-546.

Easley, D., Engle, R.F., O'Hara, M. and Wu, L. (2008), “Time-varying arrival rates of informed and uninformed trades", Journal of Financial Econometrics, Vol. 6 No. 2, pp. 171-207.

Easley D., and O'Hara M., (1987). "Price, trade size, and information in securities markets. Journal Financial Economics 19(1):69-90.

Easley D., Kiefer N, O'Hara M., (1996a), "Cream-skimming or profitsharing? The curious role of purchased order flow". Journal of Finance. 51(3):811-833

Easley D., Kiefer N, O'Hara M, and Paperman J., (1996b) Liquidity, information and infrequently traded stocks. Journal of Finance, 51(4):1405-1436

Easley D., Kiefer N, and O'Hara M., (1997), "One day in the life of a very common stock". Review of Financial Studies, 10(3):805-835

Easley D., O'Hara M., and Saar G., (2001) "How stock splits affect trading: a microstructure approach?", Journal Financial and Quantitative Analysis, 36(1):25-51

Easley D., Hvidkjaer S., and O’Hara M., (2002), "Is information risk a determinant of asset returns?" Journal of Finance. 57(5):2185-2221

Easley D., and O'Hara M., (2004), "Information and the cost of capital". Journal of Finance 59(4):1553-1583

Elliott, J., Morse, D. and Richardson, G. (1984), "The association between insider trading and information announcements", The Rand Journal of Economics, Vol. 15, pp. 521-536.

Fama, E.F. and Laffer, A.B. (1971), "Information and capital markets", Journal of Business, Vol. 44 No. 3, pp. 289-298.

Finnerty, J. E., (1976a). "Insider's Activity and Insider Information: A Multivariate Analysis", Journal of Financial and Quantitative Analysis $11,205-215$

Finnerty, J. E., (1976b). "Insiders and Market Efficiency", Journal of Finance 21, pp. 1141-1148.

Fishe, R. P. H., and M. A. Robe, (2001). "The Impact of Illegal Insider Trading in Dealer and Specialist Markets", Working Paper, Financial Economics Network, Social Sciences Research Network, Internet address: www.ssm.com.

Fishman, M. J. and K. M. Hagerty, (1995). "The Mandatory Disclosure of Trades and Market Liquidity", Review of Financial Studies 8, 637 676.

Foster FD, Viswanathan S., (1990) "A theory of the interday variations in volume, variance, and trading costs in securities markets." Review of Financial Studies, 3(4):593-624 
Foster FD, Viswanathan S., (1993) "Variations in trading volume, return volatility, and trading costs: evidence on recent price formation models". Journal of Finance 48(1):187-211

Foucault, T., Sraer, D. and Thesmar, D.J. (2011), "Individual investors and volatility", The Journal of Finance, Vol. 66 No. 4, pp. 1369-1406.

Garfinkel, J. A. and M. Nimalendran, (2001). "Market Structure and Trader Anonymity: An Analysis of Insider Trading", Working Paper, Financial Economics Network, Social Sciences Research Network, Internet address: www.ssrn.com.

George TJ, Kaul G, and Nimalendran M., (1994) "Trading volume and transaction costs in specialist markets." Journal of Finance 49(4):1489-1505

Gervais, S., R. Kaniel, and D. H. Mingelgrin, (2001). "The High-Volume Return Premium", Journal of Finance 56, 877-919.

Givoly, Dan and Dan Palmon, 1985. "Insider Trading and the Exploitation of Inside Information: Some Empirical Evidence", Journal of Business 58, 69-87.

Glass, G. S., (1966). "Extensive Insider Accumulation as an Indicator of near Term Stock Price Performance", Ph.D. dissertation, Ohio State University, Columbus, Ohio.

Gleeson, K.I., (1986),"BID-ASK spreads and insider trading: Recent NASDQ evidence", PHD Dissertation, Texas AM University.

Glosten LR, and Milgrom P., (1985) "Bid, ask and transaction prices in a specialist market with heterogeneously informed traders." Journal of Financial Economics 14(1):71-100

Glosten LR, Harris LE (1988) "Estimating the components of the bid/ask spread." Journal Financial Economics 21(1):123-142

Grossman, S.J., (1976), "On the Efficiency of Competitive Stock Markets Where Trades Have Diverse Information", The Journal of Finance, Vol. 31, No. 2, , pp. 573-585

Grossman, S.J., and J.E. Stiglitz (1980), "On the Impossibility of Informationally Efficient Markets", The American Economic Review, Vol. 70, No. 3 (Jun., 1980), pp. 393-408.

Hauser, S. and E. Kraizberg, (2003) "Insider Trading around SEO Announcements" Journal of Corporate Finance, 9, pp. 183-199. (IF 2.087)

Hendershott, T., Livdan, D. and Schurhoff, N. (2015), “Are institutions informed about news?" Journal of Financial Economics, Vol. 117 No. 2, pp. 249-287.

Hillier D., Marshall A.P., (2002), "Are trading bans effective? Exchange regulation and corporate insider transactions around earnings announcements". Journal of Corporate Finance 8:393-410

Hirshleifer, J. (1971), "The private and social value of information and the reward to inventive activity", American Economic Review, Vol. 61 No. 4 , pp. $561-574$.

Holden, C. and A. Subrahmanyam, (1992). "Long-Lived Private Information and Imperfect Competition", Journal of Finance 47, 247270.

Hsieh, S.F. (2013), "Individual and institutional herding and the impact on stock returns: evidence from Taiwan Stock Market", International Review of Financial Analysis, Vol. 29 No. 4, pp. 175-188.

Huang, C.J. and C.G. Lin, (2007), "Earnings management in IPO lockup and insider trading: Evidence from Taiwan", Emerging Markets Finance and Trade, Vol. 43 No. 5, pp. 78-91.

IOSCO (International Organization of Securities Commissions) (2003), "Insider trading: how jurisdictions regulate it". Report of the Emerging Markets Committee of the International Organization of Securities Commissions

Jain, P. and M.A. Sunderman,. (2014), "Stock price movement around the merger announcements: insider trading or market anticipation?" Managerial Finance, Vol. 40 No. 8, 2014 pp. 821-843

Jaffe, J.F. (1974). "Special information and insider trading". Journal of Business, 47(3):410-428.

Jaffe, J. F., (1974a). "The effect of regulation changes on insider trading", Bell Journal of Economics and Management Science 5, 93-121.

Jarrell, G.A. and A.B. Poulsen, (1989), "Stock trading before the announcement of tender offers: insider trading or market anticipation?" Journal of Law, Economics, Organization, Vol. 5 No. 2, pp. 225-248.

Kaniel, R., Liu, S., Saar, G. and S. Titman, (2012), "Individual investor trading and return patterns around earning announcements", The Journal of Finance, Vol. 67 No. 2, pp. 639-680.

Keown, A.J. and J.M. Pinkerton, (1981), "Merger announcements and insider trading activity: an empirical investigation", The Journal of Finance, Vol. 36 No. 4, pp. 855-869.
Keown, A.J., Pinkerton, J.M. and P.J. Bolster, (1992), "Merger announcements, asymmetrical information and trading volume: an empirical investigation", Journal of Business Finance \& Accounting, Vol. 19 No. 6, pp. 901-910.

Khanna, T. and K. Palepu, (2000), "Is group affiliation profitable in emerging markets? An analysis of diversified Indian business groups", The Journal of Finance, Vol. 55 No. 2, pp. 867-891.

King, M.R. (2009), "Prebid run-ups ahead of Canadian takeovers: how big is the problem?" Financial Management, Vol. 38 No. 4, pp. 699726.

Kim, O. and R.E. Verrecchia, (1991), "Trading volume and price reactions to public announcements", Journal of Accounting Research, Vol. 29 No. 2, pp. 302-321.

Kim, O. and R.E. Verrecchia, (1997), "Pre-announcement and event-period information", Journal of Accounting and Economics, Vol. 24 No. 3, pp. 395-419.

Korczak, A., Korczak, P. and M. Lasfer, (2010), "To trade or not to trade: the strategic trading of insiders around news announcements", Journal of Business Finance \& Accounting, Vol. 37 Nos 3/4, pp. 369-407.

Kraizberg, E., (2000) "Insider Information, a Crime or a Priceable variable" The Israeli "Economic Quarterly", 47, pp. 178-190.

Kumar, R. and M. Popescu, (2014), The implied intra-day probability of informed trading, Review of Quantitative Finance \& Accounting, 42:357-371

Kyle, A.S. (1985), "Continuous auctions and insider trading", Econometrica, Vol. 53 No. 6, pp. 1315-1335.

Lakonishok J, and I. Lee, (2001), "Are insider trades informative?" Review of Financial Studies 14(1):79-111

Lee, B.S., Li, W. and S.S. Wang, (2010), "The dynamics of individual and institutional trading on the Shanghai Stock Exchange", PacificBasin Finance Journal, Vol. 18 No. 1, pp. 116-137.

Leland, H.E. (1992), "Insider trading: should it be prohibited?", Journal of Political Economics, Vol. 100 No. 4, pp. 859-887.

Lin J, and J.S. Howe, (1990) "Insider trading in the OTC market". Journal of Finance 45(4):1273-1284.

Manne H. G., Insider Trading and the Stock Market, (1966).

MacKinlay A.C., (1997) "Event studies in economics and finance". Journal of Economic Literature 35(1):13-39

Meulbroek, L.K. (1992), "An empirical analysis of illegal insider trading", Journal of Finance, Vol. 47 No. 5, pp. 1661-1699.

Minenna, M., (2003) "Insider trading, abnormal return and preferential information: supervising through a probabilistic model." Journal of Banking and Finance 27:59-86

Morgenson, G., (2006), "Whispers of mergers set off suspicious trading", The New York Times, 27 August.

Morse, D. (1980), "Asymmetrical information in securities markets and trading volume", The Journal of Financial and Quantitative Analysis, Vol. 15 No. 5, pp. 1129-1148.

Moshirian, F., Nguyen, H.G. and P. Pham, (2012), "Overnight public information, order placement, and price discovery during the preopening period", Journal of Banking and Finance, Vol. 36 No. 10, pp. 2837-2851.

Mudalige, P., Kalev, P.S., and H.N., Duong, (2016). "Individual and institutional trading volume around firm-specific announcements ", International Journal of Managerial Finance Vol. 12 No. 4, pp. 422444

Myers S.C. and N.S Majluf, (1984), "Corporate Financing and Investment Decisions when firms have information that investors do not have", Journal of Financial Economics, 1984 pp 187.

Odders-White ER, and M.J. Ready, (2006) "Credit ratings and stock liquidity". Review of Financial Studies, 19(1):119-157

Pound, J. and Zeckhauser, R. (1990), "Clearly heard on the street: the effect of takeover rumors on stock prices", Journal of Business, Vol. 63, pp. 291-308.

Pratt S.P. and Niederhoffer (1968) Market efficiency and insider trading: new evidence. $J$ Bus 61(1):25-44

Pratt, S. P. and C. W. DeVere, 1970. Relationship Between Insider Trading and Rates of Return for NYSE Common Stocks, 1960-1966, reprinted in Modem Developments in Investment Management by James

H. Lorie and R. Brealey,(1972), editors, "Investment Management: Some Readings" Prager Publishers, New York, New York

Rogoff, D. L.,(1964). The Forecasting Properties of Insider Transactions, PHD. thesis, Michigan State University, East Lansing, Michigan. 
Rozeff, M. S. and M. A. Zaman, (1988). "Market Efficiency and Insider Trading: New Evidence", Journal of Business 61, 25-44.

Sanders, R.W. and J.S., Zdanowicz, (1992), "Target firm abnormal returns and trading volume around the initiation of change in control transactions", Journal of Financial and Quantitative Analysis, Vol. 27 No. 1, pp. 109-129.

Sarkar, A. and R.A. Schwartz, (2009), "Market sidedness: insights into motives for trade initiation", The Journal of Finance, Vol. 64 No. 1 , pp. 375-423.

Smith, C. and R. Watts, (1992). "The investment opportunity set and corporate financing, dividend, and compensation policies", Journal of Financial Economics 32, 263-292.

Seyhun H.N., (1986) "Insiders' profits, costs of trading, and market efficiency". Journal of Financial Economics 16(2):189-212

Seyhun, H.N., (1988), "The information content of aggregate insider trading". Journal of Business 61(1):1-24

Seyhun, H. N., (1992). "The effectiveness of insider-trading sanctions", Journal of Law and Economics 35, 149-182.
Thalassinos E - D Maditinos and A. Paschalidis (2012), "Observing evidence of insider trading in the Athens Stock Exchange", Journal of Economic Structures 1:8

Tinic, S. M. and R.R. West, (1972). "Competition and the pricing of dealer services in the over-the-counter stock market", Journal of Financial and Quantitative Analysis 7, 1707-1728.

Tripathy, N. and R. P. Rao, (1992). "Adverse selection, spread behavior, and OTC seasoned equity offerings", Journal of Financial Research 15, 39-56.

Wilks, S. S. (1938), "The large-sample distribution of the likelihood ratio for testing composite hypotheses", Annals of Mathematical Statistics, 9: 60-62, doi:10.1214/aoms/1177732360

Vega, C. (2006), "Stock price reaction to public and private information", Journal of Financial Economics, Vol. 82 No. 1, pp. 103-133.

Venkatesh, P. C. and R. Chiang, (1986). "Information asymmetry and the dealer's bid-ask spread: A case study of earnings and dividend announcements", Journal of Finance, 1089-1102.

Copyright ( 2020- All Rights Reserved

This is an open-access article. 